DOI: $10.17516 / 1997-1370-0730$

УДК 378.147 .88

\title{
Project-Based Activity as a Mechanism of Reflection Development in Students of Psychology and Education Studies
}

\author{
Olga G. Smolyaninova*, Marina V. Rostovtseva, \\ Yulia G. Yudina, Vera V. Korshunova \\ and Yekaterina V. Potapova \\ Siberian Federal University \\ Krasnoyarsk, Russian Federation
}

Received 13.01.2021, received in revised form 15.01.2021, accepted 06.03.2021

\begin{abstract}
Purpose of the study: to theoretically substantiate and experimentally test the system of organizational and pedagogical conditions of project designing, which is regarded as a mechanism for creating the reflecting thinking in the students of psychology and education.

The research uses the methods of theoretical review and analysis of psychological and pedagogical literature related to the subject, expert view on the development of students' reflective abilities following a theoretical and systemic model of reflection and statistical data processing.

We have theoretically stated and experimentally confirmed that project activity is a mechanism for the development of such reflection components as creativity, pattern construction and objectification, provided that the project's concept includes formulation and solution of divergent tasks by the project participants; implementation involves work on a strategy and tactics of cooperation between all the project participants; and the results are realized by all participants in the process of joint and objective assessment.

A formative experiment has been carried out and resulted in identification of the requirements for the project activities' organization among the students majoring in psychology and education, there have been revealed conditions contributing to their reflective activity; questionnaires for expert assessment and monitoring the development of reflection during the project activities have been created, theoretically supported and tested.

Novelty is determined by insufficient study of the development of reflection in the process of project activities designed by the students of psychology and education field.
\end{abstract}

Keywords: project activity, reflection, psychology and education, students.

Research area: pedagogy.

\footnotetext{
(C) Siberian Federal University. All rights reserved

* Corresponding author E-mail address: smololga@mail.ru, marin-0880@mail.ru,yudish@mail.ru,wera7@mail.ru, potapowa. catia2011@yandex.ru
}

ORCID: 0000-0002-5597-6348 (Smolyaninova); 0000-0002-2042-2417 (Korshunova) 
Citation: Smolyaninova, O.G., Rostovtseva, M.V., Yudina, Yu.G., Korshunova, V.V., Potapova, Ye.V. (2021). Project-based activity as a mechanism of reflection development in students of psychology and education studies. J. Sib. Fed. Univ. Humanit. Soc. Sci., 14(3), 385-395. DOI: 10.17516/1997-13700730 .

Проектная деятельность как механизм развития рефлексии студентов психолого-педагогического направления подготовки

\author{
О.Г. Смолянинова, М.В. Ростовцева, \\ Ю.Г. Юдина, В.В. Коршунова, Е.В. Потапова \\ Сибирский федеральныий университет \\ Российская Федерачия, Красноярск
}

\begin{abstract}
Аннотация. Цель исследования - теоретически обосновать и опытноэкспериментально проверить систему организационно-педагогических условий организации проектной деятельности как механизма развития рефлексии студентов психолого-педагогического направления подготовки.

В исследовании применяли методы теоретического обзора и анализа психологопедагогической литературы в соответствии с предметом исследования, проводили экспертные наблюдения за развитием рефлексии студентов в соответствии с теоретической и системной моделью рефлексии и статистическую обработку полученных результатов наблюдений.

Теоретически обосновано и опытно-экспериментально подтверждено, что проектная деятельность является механизмом развития таких компонентов рефлексии студентов старших курсов, как креативность, схематизация и объективация, при условии, что замысел проекта включает в себя постановку и решение участниками проекта дивергентных задач, реализация включает в себя разработку стратегии и тактики кооперативного действия между всеми участниками проекта, результаты реализации осознаются всеми участниками в процессе коллективной и объективной оценки происходящего.
\end{abstract}

Проведен формирующий эксперимент, результат которого выявление системы требований к организации проектной деятельности студентов психологопедагогического направления подготовки, способствующей развитию их рефлексии. Разработаны, теоретически обоснованы и проверены на практике анкеты для экспертной оценки и мониторинга развития рефлексии в рамках организации проектной деятельности.

Новизна исследования определяется недостаточной изученностью развития рефлексии в процессе проектной деятельности студентов психологопедагогического направления подготовки.

Ключевые слова: проектная деятельность, рефлексия, психолого-педагогическое направление подготовки, студенты.

Научная специальность: 13.00.00 - педагогические науки. 


\section{Introduction}

In 2010 a team of theorists and practitioners in pedagogy and developmental psychology V. G. Vasiliev, A.K. Lukina, A.F. Luzakova, T.A. Vakhromeeva, O. G. Smolyaninova, V.V. Korshunova, Yu. G. Yudina et al., of the Institute of Pedagogy, Psychology and Sociology, at Federal State Autonomous Educational Institution of Higher Education «Siberian Federal University» proposed main educational courses in psychology and education for both bachelor and master degree.

The training of unique specialists with reflective competence is necessary for conflict preventing and settling in a multicultural educational environment of the Krasnoyarsk Krai, so this task was a priority for the Institute of Pedagogy, Psychology and Sociology. The researches assisted by the master students of psychology and education have been carried out with the financial support of the Russian Foundation for Basic Research, the Research Project 18-013-00528 «The studying of mediation practices in education for interethnic relations harmonization in a multicultural environment».

Today's changing world is highly critical and demanding as regards future specialists. In psychology and education, any professional must be able to organize developmental activities for students, with their special needs in mind, using theoretical approaches alongside with educational standards. A successful graduate must be a master of such competencies that would navigate them in new conditions of a rapidly changing reality. For an educational psychologist, a crucial skill is reflection - the ability not only to know the reasons for one's actions, but also to change their ways of acting, relying on the goals and state of interaction.

To form that reflective competence, one must build a special activity, since only that way makes it possible to organize its reflection. In our observation, a project activity is the most effective for that, as it provides for discovering and constructing new ways of action for oneself, and not receive them ready-made. The project thinking enables people to correlate their ideas, implementation and results.
I. A. Kolesnikova (2015) states that a project is now considered as a special kind of mental activity. The practice of social systems projecting under the methodology of mental activity systems (I. N. Semyonov (2002), V.M. Rozin (2002), G.P. Shchedrovitsky (2002), V. A. Petrovsky (2002), L. G. Peterson (2016); project implementation as a management procedure (I. V. Bestuzhev-Lada (2003), R. V. Len'kov (2018), L. A. Dolmatova (2016) has pushed the project methodology to education (Yu. V. Gromyko (1997), V.I. Slobodchikov (2000). We have also reviewed the works of theorists and practitioners - G. I. Utkina (2017), A. V. Bagachuk (2013), M.K. Getmanskaya (2015), N. A. Zagranichnaya (2012), F. K. Zainullina (2016), E. F. Zeer (2013), D. A. Krylov (2016), B. R. Mandel (2018), S. A. Perekalsky (2018), G. N. Popova (2014), E. A. Smagina (2015), who study the application of project method for the development of professional competencies in students and adults. Such analysis of studies in psychology and education has revealed that there is a lack in researches on how the project activities contribute to the crucial ability of a people-oriented specialist - the ability to reflect.

All this makes the point of project activity seen as a mechanism for the development of reflection in students of psychology and education even more topical.

\section{Methodology}

As we believe, the project activity of students is a mechanism which helps to develop their reflection on the condition that:

- concept helps the participants to form and solve divergent tasks;

- implementation involves a design of strategy and tactics for cooperation between all the participants;

- process, results and prospects of the project are understood by all the participants during collective and objective assessment of their performance.

Using the above-done theoretical review, as well as comprehensive research experience in humanities, we are keen to ground our research hypothesis. 
The situation with varying degree of «uncertainty created by different problems stimulates creative activity, since their solution involves the search for different approaches, even the most incredible options» (Safonova, 2017). This means that students can construct their own ideas of task's staging and solutions by interacting with the others. Due to uncertainty and that there are different ways of solving the problems, various challenges encourage participants to build communication. Thus, to find a solution, a cooperation between the participants is necessary, since it is impossible to work otherwise.

As the project on a certain problem formulation and solution ends, it is necessary to record its implementation results and to correlate them with the intention. An inter-discussion of the results helps the participants to mark obstacles and ways to overcome them, the organizer receives feedback from both project participants and experts, which allows assessing one's own activities.

Then, there is the obvious question: how do the above conditions contribute to the development of students' reflection? The review of the works by A. A. Bekhoyeva (2017), N. B. Koroleva (2015), V. G. Vasiliev, Yu. G. Yudina (2014), O.S. Raskolovskaya (2018), V. N. Raskalinos (2017)., V. K. Ryabtsev (2018), A. Yu. Ustyuzhina (2019), M.A. Chen (2019), B. Christine (2019), L.E. Ferguson (2017), N. Fernandez (2014), L. Kohlberg (2002), D. B. Miele (2017), K.E. Stanovich (2015), B. Williams (2001) reveals that the understanding of reflection should be systemic, represent a set of reflective actions, which is mastered in project activities. In our research, we follow N. V. Galkina (1987), who models reflection as a system for mastering one's activity, creative attitude to it, its design, pattern construction and objectification. The above settings for organizing project activities become a mechanism for the students to master this system of reflective actions.

Divergent tasks' design requires an active position from the project organizer, who acts as a scriptwriter and a specialist in search for their solution, thereby providing an opportunity to master a skill of organizing their own and others' activities. In designing a solution for dif- ferent problems, the organizers, together with their teachers, forecast possible ways out and tools to be found by the project participants, and, therefore, they master the project aspect of activity. The search for possible non-standard solutions to the problems and the correspondent forecasting enables creativity in reflection both among the organizers and participants. Pattern construction enables students to develop and test the strategy and tactics in solving the problem as a certain logical work-scheme with hunting for the participants. As the project for setting and solving divergent tasks ends, a reflective procedure between the project developers, participants and experts is organized: it opens an impartial assessment of individual activities, as well as recording some educational results and discovering achievements and difficulties on the way of solving it. Upon this, a collective reflective procedure helps to develop objectification.

We have just described in brief the theoretical basis for our research hypothesis, that brings us further to test it. But first, let us understand the experiment's structure.

As part of bachelors and masters' educational and professional internship in psychology and pedagogy, we have been organizing a Festival of trainings «Development and Creativity» for two years. The festival is targeted at the students of high schools (which specialise in pedagogy and psychology), junior bachelors and masters in psychology and education. The hosts of the Festival are senior students. Through the course of «Reflexive workshops», two months before the Festival, the senior students are developing their own project on setting and solving different problems.

At the start and the end of the project, the organizers filled up personal questionnaires, aimed at revealing the level of development of the structural components of reflection. The questionnaire included 26 questions, grouped by the reflection aspects: mastering one's profession, design, pattern construction, objectification and creativity. Next when the sites of the Festival stopped working, the mentors started a brainstorming session with the participants and experts on the results; they wrote a reflexive essay, in which they were describing to what 
extent they managed to realize the idea, what challenges they faced, performing the project, what achievements they obtained, how the findings relate to the concept correlated with the project. The structure of essay was also designed in advance, based on a multi-component reflection model by N. V. Galkina. The works were then assessed by the experts (teachers), who gave marks for each structural component of reflection to the student - organizer - before and after.

There are some examples of different problems, setting and solving of which was organized by the senior students. On «Time management» site the participants were asked to create an organizational map of the means required for efficient time management; «Storytelling» was aimed at working out and presenting one's own life story according to the principles of storytelling; on «Mnemonics» the participants were to discover new ways of memorization, using the principles of mnemonics; on «Save the Unicorn» they were going to develop a team strategy and tactics to solve the problem of maximizing one's profit, without posing any harm to living creatures, i. e. unicorns; on «Tags» - to master the skills of non-verbal communication and tackle certain questions by using them.

The two-year sampling involved 36 senior students of bachelor and master's degrees in psychology and education. The research results have been statistically processed using the $\chi^{2}$ measure.

\section{Findings}

In assessing «the efficiency of the requirements proposed for the organization of project activities as a mechanism for development of reflection, we will consider the data obtained from the students' questionnaires before and after the events, as well as expert assessments» (Yudina, Belova, Dreitser, 2020).

Table 1 shows the data on the dynamics of reflection components development, got from the assessments of the students (organizers) and experts. Namely, there are mastering the profession (MP), and construction component (CC), pattern construction component (PC), objectification component (OC) and creativity $(\mathrm{C})$. Regarding the information in student questionnaires and expert assessments taken before and after the sites, the organizers (students) were marked with low, medium or high levels in certain reflection components. Next, we have observed the amount of positive, zero and negative shifts in the reflection components development when transferring from project defence (before) to its implementation (after).

Relying on Table 1, Fig. 1 presents the data on the number of positive shifts among students and experts - to compare their assessments and to determine whether there is a statistically significant difference between them or not.

In Fig. 1, the black curve shows the experts' assessment of positive shifts in the reflection components in experts, while the grey one - the students' assessment. A sample of 36 students is organized vertically, and the reflection components are located along the horizontal axis: mastering the profession (MP), and construction component (CC), pattern construction component (PC), objectification component (OC) and creativity (C).

Table 1. Dynamics of reflection components development measured by the students and experts responds before/after the activities on the sites

\begin{tabular}{|l|c|c|c|c|c|c|c|c|c|c|}
\hline \multicolumn{1}{|c|}{ Respondents } & \multicolumn{4}{c|}{ STUDENT } & \multicolumn{5}{c|}{ EXPERT } \\
\hline Indicators/reflection components & MP & CC & PC & OC & C & MP & CC & PC & OC & C \\
\hline Positive shift (people) & 0 & 4 & 30 & 24 & 32 & 8 & 5 & 28 & 22 & 27 \\
\hline Zero shift (people) & 27 & 30 & 2 & 6 & 4 & 20 & 28 & 6 & 10 & 7 \\
\hline Negative shift (people) & 9 & 2 & 4 & 6 & 0 & 8 & 3 & 2 & 4 & 2 \\
\hline Total sample (people) & 36 & 36 & 36 & 36 & 36 & 36 & 36 & 36 & 36 & 36 \\
\hline
\end{tabular}




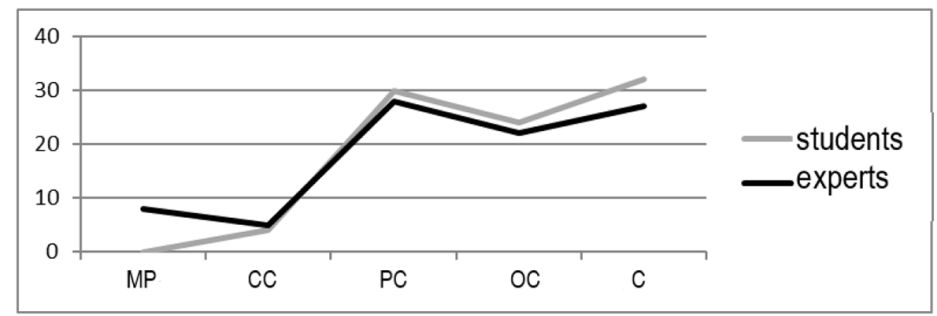

Fig. 1. Positive shifts in reflection components development

Let us formulate some statistical hypotheses:

$\mathrm{H}_{0}$ : students do not have statistically significant differences in the number of positive shifts in the reflection components development in comparison with the experts.

$\mathrm{H}_{1}$ : students have statistically significant differences in the number of positive shifts in the reflection components development in comparison with the experts.

In Table 2, let us enlist the results of data statistical processing done by the means of the $\chi 2$ measures.

Degrees of freedom are $(5-1)(2-1)=4$. According to the table of values, if $\alpha=0.05$, then $9.12<9.488$, i. e., $\chi^{2}$ emp. $<\chi^{2}$ rc. Thus, $\mathrm{H}_{0}$ is accepted. The students have no statistically significant differences in the number of positive shifts in the reflection components development in comparison with the experts' assessments.
Also, regarding the data in Table 1, we have built the graphs and tables for zero and negative shifts. According to the table with the $\chi 2$ measure, if $\alpha=0.05$ for zero shifts, then 4 , $908<9.488$, i. e., $\chi 2$ emp. $<\chi 2$ rc., and for negative shifts $3.293<9.488$, i. e., $\chi 2$ emp. $<\chi 2$ rc. This means that students do not have statistically significant differences in the number of zero and negative shifts in the reflection components development. Thus, the analysis has shown an inter-expert reliability or observer reliability and can be then trusted due to an appropriate theoretical basis - multi-component model of reflection by N. V. Galkina, who produced a questionnaire for assessing the dynamics (students) and reflective essay (experts).

Since there is no statistically significant difference between these assessments, indeed, there is a high correlation between them, it is enough to consider just one type, e. g., the students. Based on Table 1, Table 2 includes the

Table 2. Statistic processing of the number of positive shifts before/after the sites

\begin{tabular}{|c|c|c|c|c|c|}
\hline Respondent & Components & $\begin{array}{c}\text { Empirical } \\
\text { frequency } \mathrm{n}_{\mathrm{i}}\end{array}$ & $\begin{array}{l}\text { Theoretical } \\
\text { frequency } \check{n}_{i}\end{array}$ & $\left(\mathrm{n}_{\mathrm{i}}-\breve{\mathrm{n}}_{\mathrm{i}}\right)^{2}$ & $\left(\mathrm{n}_{\mathrm{i}}-\check{\mathrm{n}}_{\mathrm{i}}\right)^{2}: \check{\mathrm{n}}_{\mathrm{i}}$ \\
\hline \multirow[t]{5}{*}{ STUDENTS } & PM & 0 & 4 & 16 & 4 \\
\hline & $\mathrm{CC}$ & 4 & 4,5 & 0,25 & 0,06 \\
\hline & $\mathrm{PC}$ & 30 & 29 & 1 & 0,03 \\
\hline & $\mathrm{OC}$ & 24 & 23 & 1 & 0,04 \\
\hline & $\mathrm{C}$ & 32 & 29,5 & 6,25 & 0,21 \\
\hline \multirow[t]{5}{*}{ EXPERTS } & PM & 8 & 4 & 16 & 4 \\
\hline & $\mathrm{CC}$ & 5 & 4,5 & 2,25 & 0,5 \\
\hline & $\mathrm{PC}$ & 28 & 29 & 1 & 0,03 \\
\hline & $\mathrm{OC}$ & 22 & 23 & 1 & 0,04 \\
\hline & $\mathrm{C}$ & 27 & 29,5 & 6,25 & 0,21 \\
\hline Total & & 180 & 180 & & 9,12 \\
\hline
\end{tabular}


Olga G. Smolyaninova, Marina V. Rostovtseva... Project-Based Activity as a Mechanism of Reflection Development...

Table 3. Positive shifts in reflection development by students' assessments

\begin{tabular}{|l|c|c|c|c|}
\hline Effects / Reflection components & $\begin{array}{c}\text { Pattern } \\
\text { construction } \\
\text { component (PC) }\end{array}$ & $\begin{array}{c}\text { Objectivation } \\
\text { component (OC) }\end{array}$ & Creativity (C) & $\begin{array}{c}\text { Total } \\
\text { (approximate } \\
\text { average value) }\end{array}$ \\
\hline «Effect»: positive shift & $30(83 \%)$ & $24(67 \%)$ & $32(89 \%)$ & $29(81 \%)$ \\
\hline «No effect»: /negative shift & $6(17 \%)$ & $12(33 \%)$ & $4(11 \%)$ & $7(19 \%)$ \\
\hline Sampling - people (\%) & $36(100 \%)$ & $36(100 \%)$ & $36(100 \%)$ & $36(100 \%)$ \\
\hline
\end{tabular}

results for the reflection components with positive dynamics.

Table 3 shows us the number of positive shifts in the development of such components as pattern construction; indicators of objectification and creativity are almost 4 times higher than the sum of zero and negative shifts, which proves the statistical significance of such positive dynamics. Mastering of profession and construction component statistically remain the same: this can be seen both from the data in Table 1 and Fig. 1. Are there any explanations for that?

As the students' results show, the MP component has not changed, while the expert assessments demonstrate a slight increase $(8$ people out of 36, Fig. 1). It can be reasoned by the fact that the site was designed in advance: the students understood the logic of organizing activities and confidently implemented it in real life. According to the experts, a small part of the students was able to strengthen themselves in this way, by finding interesting and never-made-before solutions during the site.

The construction component (CC) has remained largely the same. This suggests that the concept was designed together with the teachers before the site; the idea was realized during the festival and nobody thought over the concept at that time. And indeed, this was impossible, since redesign can take place only after the project is implemented and fully comprehended by the students.

Creativity (C) has demonstrated a statistic leap, which confirms the possibility of realizing initiatives and deeply understanding them, as the students developed and implemented their own project, and the experts confirmed this.

Pattern construction (PC) has become significantly higher after the site was done. That supports the idea that in the questionnaires, the organizers could split their own activities into structural elements and, while reflexing, present them as a diagram, and the experts confirmed this in their assessment.

Objectification (OC) has also changed, since the participants began to more clearly and objectively evaluate their project and its implementation after the site, which is also seen from the experts' assessments.

\section{Discussion}

The modern world is changing fast, thereby creating uncertainty in the future. New technologies influence the labour market, so it is not enough to learn just a narrow major of study. One must be able to stay in tune with changing environment and possess universal competencies, one of which is reflection. This skill provides an opportunity to adapt to shifts. Thus, in the learning process, students need to master the ability to reflect. Since it allows one to be aware of the actions done, to change activities accordingly, and gives an opportunity to create new ways of action that will be effective when applied to any new situation.

Among the above-reviewed foreign researches, the importance of reflection for effective professional development is emphasized by V. Christine (2019), who analyses the processes of professional development in young entrepreneurs. V. Williams (2001) argues and theoretically grounds that «the development of reflection should be inextricably linked with professional development and can develop through an active, repetitive and guided practice». L. E. Ferguson (2017) considers the importance of reflection development in pedagogy as an «internal dialogue», which permits correlating the goals of teaching with the way 
of teaching and the context - aims of schools, community and parents. The importance of reflective thinking for the students' development is also emphasized in the works of R.E Silver (2016), P. C. Abrami (2015). Evidently, the role of developing students' reflection during the internship is marked by the international scientific community, both theorists and practitioners. However, the question of how to measure the formation of students' reflection remains unresolved, since this does not meet standard assessment procedures. This problem is especially revealed in his article by K. E. Stanovich (2016), who concludes that there are still no tools for measuring heuristic, reflective, rational, predictive features of thinking, and intelligence tests do not provide this.

The importance of considering the systemic and multicomponent structure of reflection is validated by the results of recent international studies by P.A. Alexander (2017), F.C. Feucht (2017). The Russian scientists theorists and methodologists - also consider reflection as a systemic and linking feature that provides transitions in thinking and communication between people in the process of setting and solving research and applied problems (V.M. Rozin (2002), G.P Shchedrovitsky (2002), V. A. Petrovsky (2002)). But the analysis of reflection components formation is still poorly understood.

The scientific novelty of this research lies in creating a method for analyzing the reflection development in students relying on the multi-component and system model of reflection by N. V. Galkina. Thus, our method has a construct validity. Based on the results of the experimental work, the method for analyzing the reflection components development has been tested in the project activities of students and passed an expert assessment, which meets the requirements of inter-expert reliability.

The issues of project learning, treated as a modern and in-demand, are widely addressed in foreign studies. In recent studies, T. Markham, J. Larmer, J. Ravitz (2003), R. J. Newell (2003), J. R. Savery (2006), D.F Wood (2003) discuss the possibilities and results of PBL (Project based learning). Regarding the current review on the findings, we have concluded that PBL training is aimed at creating a final product by students and demonstrating it, and this is where it all ends. But this limits the opportunities for professional development and training of students, since the development stage is provided only after the students rethink the process and the results of the project. This is verified by a recent study by M. A. Chen (2019), which proves the use of «reflective procedures in the process of educational design significantly improves students' results». In this work, we have included reflective procedures both in the project's setting and implementation, and in redesigning and shaping new tasks. To ensure the students' individuality in project activities, we have asked our students to use divergent problems that are everything but ready-made and unambiguous. These tasks require students to reflect on their own knowledge and reasons for a successful solution.

Ultimately, in this study, we have set and solved an integrated research task that is relevant for the modern foreign and national psychology and pedagogics, i. e., «how, in the process of developing and implementing students' projects, one can ensure a multicomponent structure of reflection and confirm this with an appropriate analysis?»

We theoretically substantiated and experimentally tested the system of organizational requirements for the students' project activities in developing their creativity, pattern construction and objectification as reflection components:

- a project for setting and solving different problems proposed by the senior students;

- project implementation as joint search activities of project participants in order to effectively solve the various tasks set by the senior students;

- reflection in cooperation with the project participants and experts after the project has finished for an integrated and objective assessment of the process, project results and its prospects.

Regarding the results of the experimental work, we have revealed a statistically significant positive dynamics in the development of such reflection components as creativity, pattern construction and objectification. This 
suggests that the development and implementation of a project for setting and solving different problems are individual processes that allow the students to discover new things in their profession, to show their creativity - this is evidenced by their increased creativity. The development and implementation of the project were organized in such a way that it enabled the students to decompose their own activities for themselves and for the participants following a certain logical scheme, and this led to a leap in the pattern construction component. And awareness of their own difficulties and achievements, joint assessment of the results caused them to objectify their action, that is, to look at themselves from above and conduct an impartial analysis of their actions, which ensured higher objectification.

\section{Conclusion}

Reflection means a tool for changing students' own activities, a basis for mastering their profession; it has a multicomponent structure with the following components: mastering the profession, construction of creativity and patterns, and objectification. According to the research results, an effective activity for the development of such reflection components as creativity, pattern construction, and objectification in senior students of psychology and pedagogics is project activity, which is seen as a joint setting and solution of different tasks. Now, we come to formulate the questions for further research: what are the requirements for the project's content in junior students, that can help to develop reflection in them; what reflection components can be mastered better in the process of their project activities. We believe that junior students can only be participants in the implementation of someone's project and can design their own search, creative actions within this project. But to verify this assumption, a theoretical justification and organization of new experimental work is required.

\section{References}

Abrami, P.C. (2015). Strategies for Teaching Students to Think Critically: A Meta-Analysis. In Review of Educational Research, 85 (2), 275-314.

Alexander, P.A. (2017). Reflection and Reflexivity in Practice Versus in Theory: Challenges of Conceptualization, Complexity, and Competence. In Educational Psychologist, 52 (4), 307-314.

Bagachuk, A.V. (2013). Organization of Project Activities in Future Teachers of Mathematics: monograph. Krasnoyarsk State Pedagogical University.

Bekhoyeva, A.A. (2017). Designing a Program for the Development of Professional and Pedagogical Reflection of Future Teachers Based on Reflexive-Activity Approach. In National Psychological Journal, $1,56-63$.

Bestuzhev-Lada, I.V. (2003). Social Forecasting. Russian Pedagogical Society.

Chen, M.A. (2019). A reflective thinking-promoting approach to enhancing graduate students' flipped learning engagement, participation behaviors, reflective thinking and project learning outcomes. In British Journal of Educational Technology, 50(5), 2288-2307.

Christine, B. (2019). Does Reflection Help Students to Develop Entrepreneurial Capabilities? In Small Business Management, 57(3), 1157-1171.

Dolmatova, L.A. (2016). Methodology and Conditions for Project Culture Development in Teachers on the «Knowledge Management» basis. In Journal of Saint-Petersburg Juridical Academy, 2 (31), $122-128$.

Ferguson, L.E. (2017). Changing Teachers' Epistemic Cognition: A New Conceptual Framework for Epistemic Reflexivity. In Educational Psychologist, 52 (4), 242-252.

Fernandez, N. (2014). What is Reflection? A Conceptual Analysis of Major Definitions and a Proposal of a Five-Component Model. In British Journal of Educational Technology, 48(12), 1176-1189.

Feucht, F.C. (2017). Moving Beyond Reflection: Reflexivity and Epistemic Cognition in Teaching and Teacher Education. In Educational Psychologist, 52 (4), 234-241.

Galkina, N.V. (1987). The Problem of Psychological Functions of Reflection in Game Learning. In Game Modeling: Methodology and Practice, 1, 38-48. 
Getmanskaya, M.K. (2015). Psychological and Age-Related Characteristics of the Process of Teaching Adults. In Pedagogical Skill and Pedagogical Technologies, 2, 83-87.

Gromyko, Yu.V. (1997). Project Consciousness: Guidelines for Programming and Projecting in Education for Strategic Management Systems. Paideia.

Kohlberg, L. (2002). Development as the Aim of Education. In Harvard Educational Review, 4, 449 496.

Kolesnikova, I.A. (2015). Pedagogical questions about a man of future. In Lifelong Learning $-21^{s t}$ century, 2 (10).

Koroleva, N.B. (2015). The Role of Reflection in the Development of a Culture of Joint Creativity. In Azimuth of Scientific Research: Pedagogy and Psychology, 4 (13), 120-123.

Krylov, D.A. (2016). Project and Technological Culture of a Teacher: Actualization Factors, Essence of the Phenomenon, Conceptual Ideas and Possible Models for Content Implementation. In Modern ScienceIntensive Technologies, 2 (2), 334-341.

Len'kov, R.V. (2018). Social Projecting as an Issue of Socio-Managerial Discourse. In Scientific Findings: Sociology and Management, 4 (4).

Mandel, B.R. (2018). Fundamentals of Project Activity: Textbook for College Students. Direct-Media.

Markham, T., Larmer, J., Ravitz, J. (2003). Project Based Learning Handbook: A Guide to Standards Focused Project Based Learning for Middle and High School Teachers (2nd ed.). The Buck Institute for Education.

Miele, D.B. (2017). Students' Thinking About Effort and Ability: The Role of Developmental, Contextual, and Individual Difference Factors. In Review of Educational Research, 87(4), 707-735.

Newell, R.J. (2003). Passion for Learning: How Project-Based Learning Meets the Needs of $21^{\text {st }}$ Century Students. Rowman \& Littlefield Education.

Perekalsky, S.A. (2018). Basic Principles of Project Activities Organization in Students Training in Specialized Pedagogical Classes for Innovative Activities. In Pedagogical Training and Science, 3, 54-59.

Peterson, L.G. (2016). Activity and System Activity Approaches: Methodology and Experience. In Pedagogical Journal of Perm', 8, 11-19.

Petrovsky, V.A. (2002). Event Transcription of Reflective Processes. In Reflexive process and control: International Interdisciplinary Scientific and Practical Journal, 1, 51.

Popova, G.N. (2014). Professional Tests as a Means of Forming an Informed Choice for Teacher's Profession. In Professional Education in Russia and Abroad, 2 (14), 52-55.

Raskalinosv V.N. (2017). Professional Reflection of a Social Teacher. In Problems of Modern Pedagogical Education, 1, 201-207.

Raskolovskaya, O.S. (2018). Pedagogical Reflection as an Interdisciplinary Concept. In Pedagogical Sciences, 1, 71-76.

Rozin, V.M. (2002). On the Necessity of Distinguishing Between the Concepts of «Reflexion Scheme», «Reflexion Activity», and «Context of Reflection». In Reflective process and control: International Interdisciplinary Scientific and Practical Journal, 1, 46.

Ryabtsev, V.K. (2018). Reflective Consciousness of a Teacher as a way to Manage Professional Activities. In Yaroslavl Pedagogical Bulletin, 4, 223-229.

Safonova, K.I. (2017). Project Activities of University Students: Principles of Project Selection and Criteria for Project Groups Formation. In Cyberleninka. Available at: https://cyberleninka.ru/article/n/ proektnaya-deyatelnost-studentov-v-vuze-printsipy-otbora-proektov-i-kriterii-formirovaniya-proektnyhgrupp/viewer

Savery, J.R. (2006). Overview of Problem-Based Learning: Definitions and Distinctions. In Interdisciplinary Journal of Problem-Based Learning, 1(1), 9-20.

Semyonov, I.N. (2002). Philosophy of Humanization of Education and Reflexiveness of Dialogue. In Reflexive process and control: International Interdisciplinary Scientific and Practical Journal, 1, 95.

Shchedrovitsky, G.P. (2002). Reflection and Relevant Problems. In Reflexive process and control: International Interdisciplinary Scientific and Practical Journal, 1, 41. 
Silver, R.E. (2016). Provoking Reflective Thinking in Post Observation Conversations. In Journal of Teacher Education, 67(3), 203-219.

Slobodchikov, V.I. (2000). Yu. V. Gromyko. Education in Russia: Prospects in Development. In School Principle, 2, 3-12.

Smagina, E.A. (2015). Formation of Professional Competencies in Project Activities in Future Bachelors of Pedagogical Education as an Urgent Pedagogical Problem. In Pedagogical Skills and Technologies, $3,28-32$.

Stanovich, K.E. (2016). The Comprehensive Assessment of Rational Thinking. In Educational Psychologist, 51 (1), 23-34.

Ustyuzhina, A. Yu. (2019). Development of Professional and Pedagogical Reflection in Future Teachers of Vocational Training. In World of Science, Culture, Education, 2, 263-266.

Utkina, G.I. (2017). The Role of Project Activity When Forming Professional Competences in Students of Pedagogics. In Bulletin of Tomsk Pedagogical University, 4, 70-74.

Vasiliev, V.G., Yudina, Yu.G. (2014). The Structure of Human Reflexive Development in Age Dynamics as the Basis of Psychological and Pedagogical Projecting. In Psychological Science and Education, 2, $35-49$.

Williams, B. (2001). Developing Critical Reflection for Professional Practice Through Problem-Based Learning. In British Journal of Educational Technology, 34(1), $27-34$.

Wood, D.F. (2003). Problem Based Learning. In British Medical Journal, 236(7384), 328-330

Yudina, Yu.G., Belova, A.M., Dreitser, S.I. (2020). Reflexive mechanism of professional selfdetermination within the framework of practice. In Bulletin of the Krasnoyarsk State Pedagogical University named after V.P. Astafyev, 1, 130-140, DOI: https://doi.org/10.25146/1995-0861-2020-51-1-190

Zagranichnaya, N.A. (2012). Fundamentals of Project and Research Activities. Part 1: Textbook. INFRA-M.

Zainullina, F.K. (2016). Project Method of Teaching When Forming a Motivation During the Learning in Students. In Bulletin of KazGUKI, 4, 164-166.

Zeer, E.F. (2013). Psychology of Vocational Education: textbook. ACADEMIA. 